\title{
Novel Acute Myocardial Infarction Risk Stratification (nARS) System Reduces the Length of Hospitalization for Acute Myocardial Infarction
}

\author{
Kei Yamamoto, MD; Kenichi Sakakura, MD; Naoyuki Akashi, MD; Yusuke Watanabe, MD; \\ Masamitsu Noguchi, MD; Masaru Seguchi, MD; Yousuke Taniguchi, MD; Yusuke Ugata, MD; \\ Hiroshi Wada, MD; Shin-ichi Momomura, MD; Hideo Fujita, MD
}

\begin{abstract}
Background: The novel Acute Myocardial Infarction (AMI) Risk Stratification (nARS) system was recently developed based on original criteria. The use of nARS may reduce the length of hospitalization.

Methods and Results: We allocated 560 AMl patients into the pre-nARS group (before adopting nARS) or the nARS group. Patients in the nARS group were subdivided into the low $(\mathrm{L})$, intermediate $(\mathrm{I})$, and high $(\mathrm{H})$ risk groups, whereas patients in the pre-nARS group were subdivided into the equivalent $\mathrm{L}(\mathrm{eL})$, equivalent $\mathrm{I}(\mathrm{el})$, or equivalent $\mathrm{H}(\mathrm{eH})$ risk groups based on the nARS criteria. Length of coronary care unit (CCU) stay was significantly shorter in the nARS group (2.8 \pm 3.5 days) compared with the pre-nARS group (4.4 \pm 5.4 days; $P<0.001)$. Length of hospital stay was also shorter in the nARS group (9.4 \pm 8.9 days) compared with the pre-nARS group (13.4 \pm 12.8 days; $P<0.001)$. Length of $C C U$ stay was significantly shorter in the $L(1.1 \pm 1.0$ days), I $(2.8 \pm 3.5$ days), and $H$ (5.0 \pm 4.8 days) risk groups compared with corresponding eL ( $2.2 \pm 1.1$ days), el (4.4 \pm 5.4 days), and eH (7.1 \pm 7.8 days) risk groups.
\end{abstract}

Conclusions: Length of CCU and hospital stay were significantly shorter in the nARS group compared with the pre-nARS group. The use of nARS may save medical resources in the treatment of AMI in the regional health-care system.

Key Words: Acute myocardial infarction; Coronary care unit; Length of hospitalization; Risk stratification

A cute myocardial infarction (AMI) has been a major cause of death in many developed countries including Japan. ${ }^{1,2}$ Given that AMI treatment involves many medical resources and generates medical device, hospital staff, and hospitalization costs during the hospital stay, ${ }^{\mathbf{3}, 4}$ it is important to shorten the total hospitalization period and coronary care unit (CCU) period without sacrificing safety. ${ }^{5}$ Furthermore, the length of hospitalization for AMI is longer in Japan compared with Western countries, ${ }^{6}$ partly because an in-hospital rehabilitation program for AMI has not been developed in the primary percutaneous coronary intervention (PCI) era. Recently, we reported on the novel AMI Risk Stratification (nARS) system linked to an in-hospital rehabilitation program, ${ }^{7}$ which classified the AMI patients into low (L) risk, intermediate (I) risk, and high $(\mathrm{H})$ risk based on the success of primary $\mathrm{PCI}$ as well as the severity of AMI. ${ }^{7}$ The representative length of hospitalization for $\mathrm{L}, \mathrm{I}$, and $\mathrm{H}$ risk was 5 days, 7 days, and 10 days, respectively. ${ }^{7}$ We hypothesized that nARS may safely shorten the length of hospitalization in AMI patients. The purpose of this study was to compare the length of hospitalization and CCU stay before the use of

nARS with that after adopting nARS.

Methods
Study Design
We reviewed AMI patients treated at Saitama Medical
Center between April 2014 and September 2016. Given
that the nARS system came into effect on 20 April 2015,
we divided those AMI patients into the pre-nARS group
(April 2014-19 April 2015) and the nARS group (20 April
2015-September 2016). In the nARS group, the AMI risk
for each patient was discussed and determined in our daily
CCU conference on the day after admission (i.e., on the
day after primary PCI or coronary angiography). Each
patient was allocated into the L, I, or H risk groups as
previously described.7 In contrast, because each patient in
the pre-nARS group was not allocated into the L, I, or H
risk groups, we retrospectively classified each patient in the
pre-nARS group into the equivalent L (eL), equivalent I
(eI), or equivalent H (eH) risk using the nARS criteria for
the present study. In brief, the L risk must satisfy all of the
following criteria: (1) primary PCI $\leq 12 \mathrm{~h}$ from onset of

Received November 19, 2018; revised manuscript received January 17, 2019; accepted January 27, 2019; J-STAGE Advance Publication released online March 19, 2019 Time for primary review: 35 days

Division of Cardiovascular Medicine, Saitama Medical Center, Jichi Medical University, Saitama, Japan

Mailing address: Kenichi Sakakura, MD, Division of Cardiovascular Medicine, Saitama Medical Center, Jichi Medical University, 1-847 Amanuma-cho, Omiya-ku, Saitama 330-8503, Japan. E-mail: ksakakura@jichi.ac.jp

ISSN-1346-9843 All rights are reserved to the Japanese Circulation Society. For permissions, please e-mail: cj@j-circ.or.jp 
symptoms; (2) final flow grade of Thrombolysis in Myocardial Infarction (TIMI) 3 on primary PCI; (3) global ejection fraction (EF) $>40 \%$; (4) introduction of angiotensinconverting enzyme inhibitors/angiotensin II receptor blockers (ACEI/ARB) and $\beta$-blockers on the day of admission or the day after admission; (5) no high-risk comorbidities; (6) no right ventricular (RV) infarction that worsens hemodynamic status; (7) no pericardial effusion, or $<10 \mathrm{~mm}$ pericardial effusion on echocardiography; (8) no apical aneurysm; (9) no mechanical complication; and (10) no intra-aortic balloon pumping (IABP) or IABP $<48 \mathrm{~h} .{ }^{7}$ The $\mathrm{H}$ risk group must have at least one of the following criteria: (1) primary PCI $>24 \mathrm{~h}$ from onset of symptoms; (2) final flow grade TIMI $\leq 2$ on primary PCI; (3) global EF $<30 \%$; (4) unsuccessful rehabilitation test caused by residual stenosis; (5) RV infarction that worsens hemodynamic status; (6) >10 mm pericardial effusion on echocardiography; (7) apical aneurysm requiring anticoagulation therapy; (8) presence of mechanical complication; (9) requiring IABP support $>48$ h. $^{7}$ Patients who were neither L or $\mathrm{H}$ risk group were categorized as I risk. ${ }^{7}$

We included consecutive AMI patients during the study period (April 2014-September 2016). We excluded patients with AMI caused by coronary artery spasm as well as AMI patients who underwent emergency/urgent coronary bypass grafting surgery or emergency surgery for mechanical complications during hospitalization. We excluded patients with AMI caused by complications following cardiac surgery. We also excluded AMI patients who did not undergo coronary angiography. If the patients had more than 1 AMI during the study period, only the first AMI was included, and the following AMI were excluded. The patients who were managed by other departments such as general surgery were excluded. The primary endpoint was the length of CCU stay and the length of hospital stay. In-hospital cardiovascular events were also evaluated. All-cause death, cardiac death, and stent thrombosis were defined as in-hospital cardiovascular events. This study was approved by the institutional review board, and written informed consent was waived because of the retrospective study design. The data collection and storage were performed anonymously, according to the Japan Ministry of Health, Labour and Welfare guidelines.

\section{Definitions}

AMI was defined as a rise in a cardiac biomarker (preferably cardiac troponin with $\geq 1$ value above the 99th percentile upper reference limit) and with $\geq 1$ of the following: (1) symptoms of ischemia; (2) new or presumed new significant ST-segment T-wave changes or new left bundle branch block; (3) development of pathological Q waves on electrocardiogram; (4) imaging evidence of new loss of viable myocardium or new regional wall motion abnormality; and (5) identification of intracoronary thrombus on angiography, according to the universal definition. ${ }^{\mathbf{8}}$

Each nARS risk group had a specified rehabilitation program,${ }^{7}$ while the pre-nARS group did not. In brief, patients in the L risk group had to stand for 2 min on the day after primary PCI, followed by a $200-\mathrm{m}$ walk test on the day after successful 2-min standing test, and then a 500-m walk test on the day after successful 200-m walk test, followed by discharge on the day after successful 500-m walk test. ${ }^{7}$ Patients in the I risk group had a 1-day interval between each test, and the patients in the $\mathrm{H}$ risk group had a 2-day interval between each test. After suc- cessfully completing the 2-min standing test, the patient is allowed to stand without aid. After $200-\mathrm{m}$ walk test, the patient is allowed to move freely in the general ward. After $500-\mathrm{m}$ walk test, the patient is allowed to be discharged. If the patient required IABP support, mechanical ventilation, or veno-arterial extracorporeal membrane oxygenation, the rehabilitation program was postponed until the mechanical support was longer required. Risk stratification transition (from $\mathrm{L}$ risk to $\mathrm{H}$ risk or from I risk to $\mathrm{H}$ risk) occurred when the patient could not pass the scheduled rehabilitation test. Furthermore, the rehabilitation program was modified to include very high ( $\mathrm{VH}$ ) risk when H-risk patients failed the rehabilitation tests such as $200-\mathrm{m}$ walk. The $\mathrm{VH}$ risk group had a longer interval between the rehabilitation tests. ${ }^{7}$ The pre-nARS group also completed the standing test, $200-\mathrm{m}$ walk test, and $500-\mathrm{m}$ walk test before discharge. The timing or interval between each test, however, was not specified in the pre-nARS group.

Stent thrombosis was defined according to the Academic Research Consortium (ARC) definition. ${ }^{9}$ Hypertension was defined as systolic blood pressure $(\mathrm{SBP})>140 \mathrm{mmHg}$, diastolic blood pressure $>90 \mathrm{mmHg}$, or medical treatment for hypertension. Diabetes mellitus was defined as hemoglobin A1c $>6.5 \%$ or treatment for diabetes mellitus. Hyperlipidemia was defined as total cholesterol $>220 \mathrm{mg} / \mathrm{dL}$, low-density lipoprotein cholesterol $>140 \mathrm{mg} / \mathrm{dL}$, or treatment for hyperlipidemia. We also calculated estimated glomerular filtration rate (eGFR) using serum creatinine (Cr), age, weight, and gender according to the following formula: eGFR $=194 \times \mathrm{Cr}^{-1.094} \times \mathrm{age}^{-0.287}$ (male), or eGFR= $194 \times \mathrm{Cr}^{-1.094} \times \mathrm{age}^{-0.287} \times 0.739$ (female). ${ }^{10}$ Shock was defined as $\mathrm{SBP}<90 \mathrm{mmHg}$ or vasopressors required to maintain blood pressure or attempted cardiopulmonary resuscitation. EF was measured using a modified Simpson method. EF measured with the Teichholz method was adopted only when a modified Simpson method was not available. Echocardiography was evaluated during hospitalization. Most of the patients underwent echocardiography of the AMI culprit lesion after PCI. Some patients, however, underwent echocardiography of the AMI culprit lesion before PCI. RV infarction was defined as ST-segment elevation in V4R ( $\geq 1 \mathrm{~mm}$ ) or abnormal $\mathrm{RV}$ wall motion on echocardiography, accompanying clinical symptoms such as hypotension. Global Registry of Acute Coronary Events (GRACE) risk score and TIMI risk score for each patient were compared between the 2 groups (TIMI risk score was calculated only for the ST-segment elevation MI [STEMI] patients). ${ }^{11,12}$ In-hospital Diagnosis Procedure Combinations (DPC) costs was calculated based on the DPC payment system in Japan, ${ }^{\mathbf{1 3}, \mathbf{1 4}}$ which used the phased cost reduction system in the case of prolonged hospitalization.

\section{Statistical Analysis}

Data are expressed as mean \pm SD or percentage. Categorical variables are presented as $\mathrm{n}(\%)$ and were compared using the chi squared test (or Fisher's exact test for small samples). Continuous variables were compared using Student's t-test. Statistical significance was defined as a 2 -sided $\mathrm{P}<0.05$. Statistical analysis were performed with SPSS 18.0 for Windows (SPSS, Chicago, IL, USA).

\section{Results}

Between April 2014 and September 2016, a total of 560 patients were diagnosed with AMI at Saitama Medical 
Patients who were diagnosed with acute myocardial infarction in our institution between April 1st 2014 and September 31th 2016 $n=560$

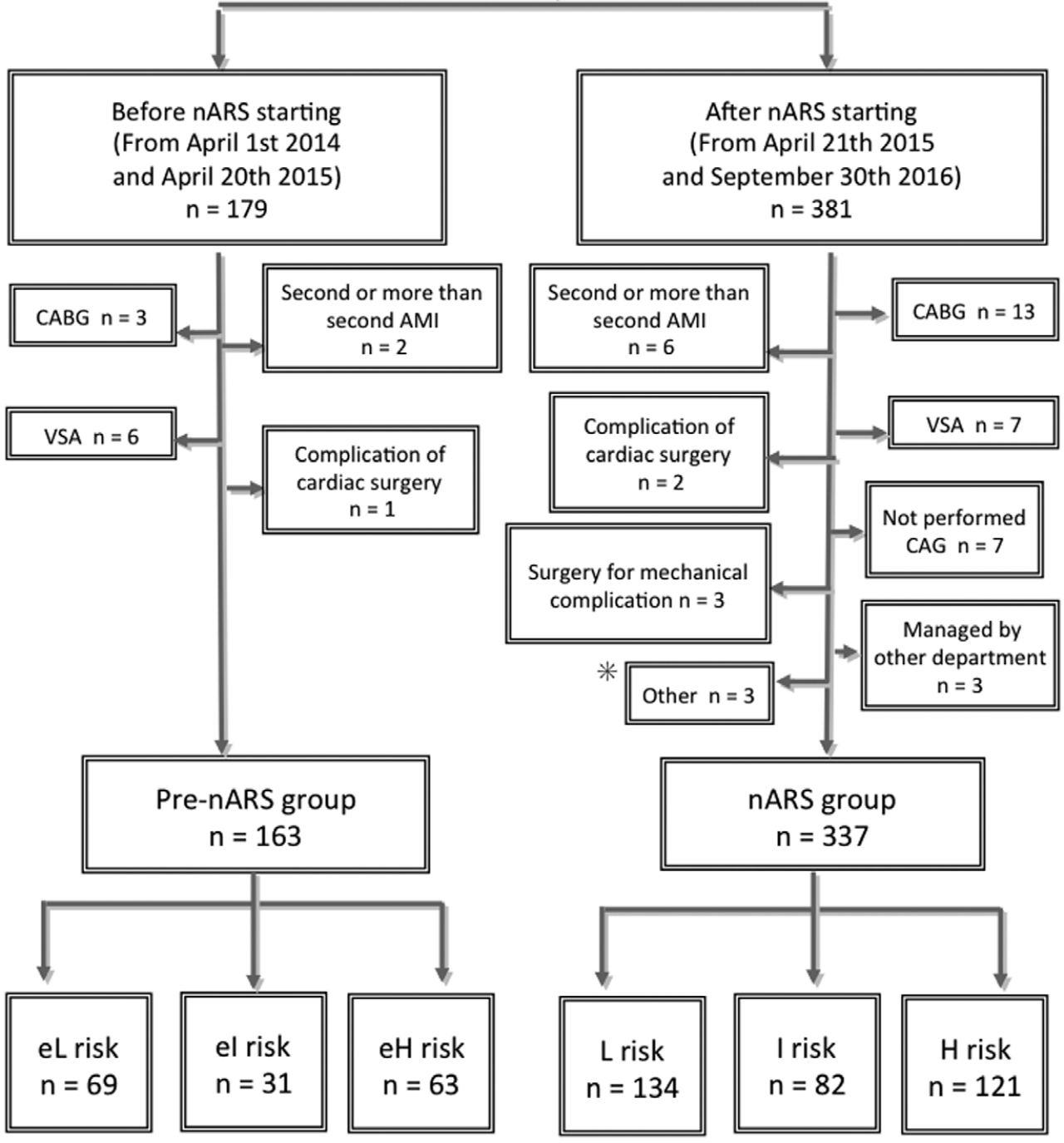

Figure. Subject selection. ${ }^{*}$ Three patients were not assigned to any risk level at the daily coronary care unit conference. Because the risk stratification in the nARS group was prospectively performed for clinical practice (not for this study), these unassigned patients were excluded from the subject group. AMI, acute myocardial infarction; CABG, coronary artery bypass grafting; CAG, coronary angiography; eH, H equivalent; el, I equivalent; eL, L equivalent; H, high; I, intermediate; L, low; nARS, novel AMI Risk Stratification; VSA, vasospastic angina.

Center: 179 in the pre-nARS group and 381 in the nARS group. Finally, 163 patients were included in the pre-nARS group, and divided into the eL risk $(\mathrm{n}=69)$, eI risk $(\mathrm{n}=31)$, and $\mathrm{eH}$ risk groups $(\mathrm{n}=63)$. ACEI/ARB and $\beta$-blockers were prescribed on the day after primary PCI in the L-risk nARS group as part of the management strategy, but this was not the case for the eL-risk pre-nARS group, because immediate introduction of ACEI/ARB and $\beta$-blockers was not emphasized in the hospital before the introduction of
nARS. With regard to the nARS group, 337 patients were selected, and were divided into the L risk $(\mathrm{n}=134)$, I risk $(\mathrm{n}=82)$, and $\mathrm{H}$ risk groups $(\mathrm{n}=121$; Figure).

Comparison of clinical characteristics between the 2 groups is given in Table 1. The prevalence of hemodialysis was significantly higher in the nARS group (8.3\%) than in the pre-nARS group $(3.1 \% ; \mathrm{P}=0.027)$. The prevalence of STEMI was higher in the pre-nARS group $(74.8 \%)$ than in the nARS group $(61.1 \% ; \mathrm{P}=0.002)$. Although both peak 


\begin{tabular}{|c|c|c|c|c|}
\hline Variable & $\begin{array}{c}\text { All } \\
(n=500)\end{array}$ & $\begin{array}{c}\text { Pre-nARS } \\
(n=163)\end{array}$ & $\begin{array}{c}\text { nARS } \\
(n=337)\end{array}$ & P-value $^{\dagger}$ \\
\hline \multicolumn{5}{|l|}{ Patient characteristics } \\
\hline Age (years) & $70 \pm 12$ & $69 \pm 13$ & $70 \pm 12$ & 0.480 \\
\hline Male & $338(67.6)$ & $117(71.8)$ & 259 (76.9) & 0.218 \\
\hline Hypertension & $423(84.6)$ & $133(81.6)$ & $290(86.1)$ & 0.195 \\
\hline Diabetes mellitus & $214(42.8)$ & $61(37.4)$ & $153(45.4)$ & 0.091 \\
\hline Hyperlipidemia & $344(68.8)$ & $102(62.6)$ & $242(71.8)$ & 0.037 \\
\hline $\begin{array}{l}\text { eGFR }<60 \mathrm{~mL} / \mathrm{min} / 1.73 \mathrm{~m}^{2} \text { at } \\
\text { admission }\end{array}$ & $191(38.2)$ & $56(34.4)$ & $135(40.1)$ & 0.219 \\
\hline Hemodialysis & $33(66.0)$ & $5(3.1)$ & $28(8.3)$ & 0.027 \\
\hline Current smoking & $140(28.0)$ & $31(19.0)$ & 109 (32.3) & 0.002 \\
\hline Previous MI & $94(18.4)$ & $27(16.6)$ & $67(19.9)$ & 0.374 \\
\hline Previous $\mathrm{PCl}$ & $94(18.4)$ & $22(13.5)$ & $72(21.4)$ & 0.035 \\
\hline Previous CABG & $18(3.6)$ & $5(3.1)$ & $13(38.6)$ & 0.657 \\
\hline Shock & $65(13.0)$ & $18(11.0)$ & $47(13.9)$ & 0.341 \\
\hline Cardiopulmonary arrest & $30(6.0)$ & $10(6.1)$ & $20(5.9)$ & 0.930 \\
\hline STEMI & $328(65.6)$ & $122(74.8)$ & $206(61.1)$ & 0.002 \\
\hline NSTEMI & $172(34.4)$ & $41(25.2)$ & $131(38.9)$ & 0.002 \\
\hline Risk classification ${ }^{\ddagger}$ & & & & 0.421 \\
\hline L risk & $203(40.6)$ & 69 (42.3) & $134(39.8)$ & \\
\hline I risk & $113(22.6)$ & $31(19.0)$ & $82(24.3)$ & \\
\hline $\mathrm{H}$ risk & $184(36.8)$ & $63(38.7)$ & $121(35.9)$ & \\
\hline Site of infarction & & & & 0.135 \\
\hline Anterior & $242(48.4)$ & $88(54.0)$ & $154(45.7)$ & \\
\hline Inferior & $173(34.6)$ & $47(28.8)$ & $126(37.4)$ & \\
\hline Posterior & 77 (15.4) & $27(16.6)$ & $50(14.8)$ & \\
\hline Not determined & $8(1.6)$ & $1(0.6)$ & $7(2.1)$ & \\
\hline Killip 1 or 2 & $396(79.8)$ & $130(79.8)$ & 266 (78.9) & 0.832 \\
\hline Killip 3 or 4 & $104(20.2)$ & $33(20.2)$ & $71(21.1)$ & 0.832 \\
\hline EF (\%) & $54.3 \pm 14.3$ & $55.2 \pm 14.1$ & $53.9 \pm 14.4$ & 0.298 \\
\hline IABP & $69(13.8)$ & $20(12.3)$ & $49(14.5)$ & 0.490 \\
\hline PCPS & $21(4.2)$ & $4(2.5)$ & $17(5.0)$ & 0.176 \\
\hline Peak CK (mU/mL) & $1,710 \pm 2,770$ & $1,936 \pm 2,712$ & $1,601 \pm 2,795$ & 0.005 \\
\hline Peak CK-MB (mU/mL) & $153 \pm 223$ & $179 \pm 230$ & $141 \pm 219$ & 0.002 \\
\hline GRACE score & $137 \pm 38$ & $137 \pm 36$ & $137 \pm 39$ & 0.705 \\
\hline TIMI risk score & $6.2 \pm 3.1$ & $5.9 \pm 2.7$ & $6.2 \pm 3.2$ & 0.078 \\
\hline \multicolumn{5}{|l|}{ Medication at discharge } \\
\hline Aspirin & $468 / 468(100)$ & $154 / 154(100)$ & $314 / 314(100)$ & - \\
\hline Thienopyridine & $445 / 469$ (94.9) & $150 / 154(97.4)$ & 295/315 (93.7) & 0.104 \\
\hline Statin & $461 / 468(9.8)$ & $153 / 154(99.4)$ & $308 / 314(98.1)$ & 0.291 \\
\hline ACEI/ARB & $420 / 468(89.7)$ & $133 / 154(86.4)$ & 287/314 (91.4) & 0.091 \\
\hline$\beta$-blocker & $419 / 468(89.5)$ & $128 / 154(83.1)$ & $291 / 314(92.7)$ & 0.002 \\
\hline
\end{tabular}

Data given as mean \pm SD or $n(\%)$. 'Student's t-test, Mann-Whitney U-test or chi-squared test. \$Pre-nARS risk classification was equivalent to nARS retrospectively. ACEI, angiotensin-converting enzyme inhibitor; ARB, angiotensin II receptor blocker; CABG, coronary artery bypass grafting; CK, creatine kinase; EF, ejection fraction; eGFR, estimated glomerular filtration rate; GRACE, Global Registry of Acute Coronary Events; H, high; I, intermediate; IABP, intra-aortic balloon pumping; L, low; MI, myocardial infarction; nARS, novel Acute Myocardial Infarction Risk Stratification; NSTEMI, non-ST-segment elevation myocardial infarction; PCl, percutaneous coronary intervention; PCPS, percutaneous cardio-pulmonary support; STEMI, ST-segment elevation myocardial infarction; TIMI, Thrombolysis in Myocardial Infarction.

creatine kinase $(\mathrm{CK})$ and $\mathrm{CK}-\mathrm{MB}$ were significantly higher in the pre-nARS group $(1,936 \pm 2,712 \mathrm{U} / \mathrm{L}$ and $179 \pm 230 \mathrm{U} / \mathrm{L})$ than in the nARS group $(1,601 \pm 2,795 \mathrm{U} / \mathrm{L}$ and $141 \pm 219 \mathrm{U} / \mathrm{L}$; $\mathrm{P}=0.002$ ), other parameters regarding severity of AMI were similar between the 2 groups. Beta-blockers were more frequently prescribed at discharge in the nARS group $(92.4 \%)$ than in the pre-nARS groups $(83.1 \% ; \mathrm{P}=0.002)$.
Comparison of lesion and procedural characteristics is shown in Table 2. The prevalence of triple-vessel disease was significantly higher in the nARS group $(24.0 \%)$ compared with the pre-nARS group $(9.8 \% ; \mathrm{P}<0.001)$. The frequency of thrombus aspiration was higher in the prenARS group (53.1\%) than in the nARS group $(19.7 \%$; $\mathrm{P}<0.001)$. 


\begin{tabular}{|c|c|c|c|c|}
\hline Variables & $\underset{(n=500)}{\text { All }}$ & $\begin{array}{c}\text { Pre-nARS } \\
(n=163)\end{array}$ & $\begin{array}{c}\text { nARS } \\
(n=337)\end{array}$ & P-value ${ }^{\dagger}$ \\
\hline No. vessels & & & & $<0.001$ \\
\hline 1 & $239(47.8)$ & $95(58.3)$ & $144(42.7)$ & \\
\hline 2 & $164(32.8)$ & $52(31.9)$ & $112(33.2)$ & \\
\hline 3 & $97(19.4)$ & $16(9.8)$ & $81(24.0)$ & \\
\hline \multicolumn{5}{|l|}{ First TIMI } \\
\hline 0 or 1 & $309(61.8)$ & $102(62.6)$ & 207 (61.4) & 0.804 \\
\hline 2 or 3 & $191(38.2)$ & $61(37.4)$ & $130(38.6)$ & 0.804 \\
\hline \multicolumn{5}{|l|}{ Final TIMI } \\
\hline 0 or 1 or 2 & $46(9.2)$ & $18(11.0)$ & $28(8.3)$ & 0.321 \\
\hline 3 & $454(90.8)$ & $145(89.0)$ & $309(91.7)$ & 0.321 \\
\hline Medication only & $20(4.0)$ & $2(1.2)$ & $18(5.3)$ & 0.028 \\
\hline $\mathrm{PCl}$ & $480(96.0)$ & $161(98.8)$ & $319(94.7)$ & 0.028 \\
\hline Final PCI & & & & 0.001 \\
\hline Drug-eluting stent & $423 / 480(88.1)$ & 135/161 (83.9) & 288/319 (90.3) & \\
\hline Bare-metal stent & $34 / 480(7.1)$ & 21/161 (13.0) & 13/319 (4.1) & \\
\hline Stentless $\mathrm{PCl}^{\ddagger}$ & $23 / 480(4.8)$ & 5/161 (3.1) & $18 / 319(5.6)$ & \\
\hline Aspiration & $149 / 480(31.0)$ & $86 / 161(53.4)$ & $63 / 319(19.7)$ & $<0.001$ \\
\hline Access site & & & & 0.031 \\
\hline Radial artery & $247 / 480$ (51.5) & $94 / 161(58.4)$ & $153 / 319(48.0)$ & \\
\hline Brachial artery & $15 / 480(3.1)$ & 7/161 (4.3) & $8 / 319(2.5)$ & \\
\hline Femoral artery & $218 / 480(45.4)$ & 60/161 (37.3) & $158 / 319(49.5)$ & \\
\hline Catheter size (Fr) & & & & 0.021 \\
\hline 6 & $309 / 480(64.4)$ & $117 / 161(72.7)$ & $192 / 319(60.2)$ & \\
\hline 7 & $166 / 480(34.6)$ & 42/161 (26.1) & $124 / 319$ (38.9) & \\
\hline 8 & $5 / 480(1.0)$ & 2/161 (1.2) & $3 / 319(0.9)$ & \\
\hline
\end{tabular}

Data given as $\mathrm{n}(\%)$. 'Student's t-test, Mann-Whitney U-test or chi-squared test. $\neq$ Includes plain old balloon angioplasty, drug-coated balloon angioplasty, aspiration only etc. Abbreviations as in Table 1.

Comparison of clinical outcome between the pre-nARS and nARS groups, and between the corresponding risk groups, is given in Table 3. Length of CCU stay was significantly shorter in the nARS group $(2.8 \pm 3.5$ days $)$ compared with the pre-nARS group ( $4.4 \pm 5.4$ days; $\mathrm{P}<0.001)$. The length of hospital stay was also shorter in the nARS group ( $9.4 \pm 8.9$ days) compared with the pre-nARS group $(13.4 \pm 12.8$ days; $\mathrm{P}<0.001)$. The length of $\mathrm{CCU}$ stay was significantly shorter in the $\mathrm{L}$ risk group $(1.1 \pm 1.0$ days) compared with the eL risk group $(2.2 \pm 1.1$ days; $\mathrm{P}<0.001)$, and the length of hospital stay was also shorter in the $\mathrm{L}$ risk group (5.5 \pm 3.0 days) compared with the eL risk group $(8.0 \pm 2.5$ days; $\mathrm{P}<0.001)$. The length of $\mathrm{CCU}$ stay was significantly shorter in the I risk group $(2.8 \pm 3.5$ days $)$ compared with the eI risk group ( $4.4 \pm 5.4$ days; $\mathrm{P}<0.001)$, and the length of hospital stay was also shorter in the I risk group (8.0 \pm 2.5 days) compared with the eI risk group $(11.7 \pm 4.3$ days; $\mathrm{P}<0.001)$. The length of $\mathrm{CCU}$ stay was significantly shorter in the $\mathrm{H}$ risk group (5.0 \pm 4.8 days) compared with the eH risk group (7.1 \pm 7.8 days; $\mathrm{P}=0.004)$, and the length of hospital stay was also shorter in the $\mathrm{H}$ risk group (14.6 \pm 12.7 days) compared with the $\mathrm{eH}$ risk group $(20.1 \pm 18.3$ days; $\mathrm{P}=0.002)$.

The frequency of unplanned readmission in $\leq 28$ days was similar between the 2 groups $(2.5 \%$ in the pre-nARS group and $5.0 \%$ in the nARS group, $\mathrm{P}=0.176$ ). The frequency of unplanned readmission caused by cardiovascular events was also similar between the 2 groups $(2.5 \%$ in the pre-nARS group and $3.0 \%$ in the nARS group, $\mathrm{P}=0.744$ ).
The DPC cost was similar between the 2 groups ( $¥ 210,695 \pm$ 162,377 in the pre-nARS group and $¥ 199,971 \pm 133,721$ in the nARS group, $\mathrm{P}=0.425$ ).

\section{Discussion}

The present study involved 500 patients with AMI, who were divided into the pre-nARS group and the nARS group. Length of CCU stay and of hospital stay was significantly shorter in the nARS group compared with the pre-nARS group without increasing in-hospital events or unplanned readmission. Furthermore, because the nARS system stratifies AMI patients into L, I, and $\mathrm{H}$ risk groups according to the original criteria, ${ }^{7}$ the patients in the pre-nARS group were retrospectively stratified into the eL, eI, and eH risk groups using the same criteria. Length of CCU stay and of hospital stay was significantly shorter in the $\mathrm{L}, \mathrm{I}$, and $\mathrm{H}$ risk groups compared with the corresponding $\mathrm{eL}, \mathrm{eI}$, and $\mathrm{eH}$ risk groups. This suggests that using nARS may reduce the length of CCU and of hospital stay for AMI of varying severity, indicating the significant usefulness of nARS for reducing medical resources.

Although peak CK was higher in the pre-nARS group than in the nARS group, GRACE score and TIMI risk score were similar between the 2 groups, suggesting that the severity of AMI was also similar between the 2 groups. Given that the length of hospitalization generally depends on the severity of disease, ${ }^{15}$ the length of hospitalization is usually similar between 2 groups if the severity of disease 
Table 3. Clinical Outcome vs. nARS and Risk Level Status

\begin{tabular}{|c|c|c|c|c|}
\hline Variable & $\begin{array}{c}\text { All } \\
(n=500)\end{array}$ & $\begin{array}{c}\text { Pre-nARS } \\
(n=163)\end{array}$ & $\begin{array}{c}\text { nARS } \\
(n=337)\end{array}$ & P-value ${ }^{\dagger}$ \\
\hline All-cause death (in-hospital) & $32(6.4)$ & $9(5.5)$ & $23(6.8)$ & 0.577 \\
\hline Cardiac death (in-hospital) & $26(5.2)$ & $8(4.9)$ & $18(5.3)$ & 0.838 \\
\hline Stent thrombosis (in-hospital) & $2(0.4)$ & 0 & $2(0.6)$ & 0.324 \\
\hline Length of CCU stay (days) & $3.3 \pm 4.3$ & $4.4 \pm 5.4$ & $2.8 \pm 3.5$ & $<0.001$ \\
\hline Length of hospital stay (days) & $10.7 \pm 10.5$ & $13.4 \pm 12.8$ & $9.4 \pm 8.9$ & $<0.001$ \\
\hline Unplanned readmission in $\leq 28$ days (all) & $21(4.2)$ & $4(2.5)$ & $17(5.0)$ & 0.176 \\
\hline Unplanned readmission in $\leq 28$ days (cardiovascular) & $14(2.8)$ & $4(2.5)$ & $10(3.0)$ & 0.744 \\
\hline \multirow[t]{2}{*}{ DPC cost $(¥)$} & $203,467 \pm 143,616$ & $210,695 \pm 162,377$ & $199,971 \pm 133,721$ & 0.425 \\
\hline & $\begin{array}{l}\text { eL and } L \text { risk } \\
(n=203)\end{array}$ & $\begin{array}{l}\text { eL risk } \\
(n=69)\end{array}$ & $\begin{array}{c}\text { L risk } \\
(n=134)\end{array}$ & P-value $^{\dagger}$ \\
\hline All-cause death (in-hospital) & 0 & 0 & 0 & - \\
\hline Cardiac death (in-hospital) & 0 & 0 & 0 & - \\
\hline Stent thrombosis (in-hospital) & 0 & 0 & 0 & - \\
\hline Length of CCU stay (days) & $1.4 \pm 1.1$ & $2.2 \pm 1.1$ & $1.1 \pm 1.0$ & $<0.001$ \\
\hline Length of hospital stay (days) & $6.3 \pm 3.1$ & $8.0 \pm 2.5$ & $5.5 \pm 3.0$ & $<0.001$ \\
\hline Unplanned readmission in $\leq 28$ days (all) & $5(2.5)$ & $2(2.9)$ & $3(2.2)$ & 0.774 \\
\hline Unplanned readmission in $\leq 28$ days (cardiovascular) & $4(2.0)$ & $2(2.9)$ & $2(1.5)$ & 0.495 \\
\hline \multirow[t]{2}{*}{ DPC cost $(¥)$} & $147,115 \pm 59,952$ & $153,410 \pm 48,055$ & $143,874 \pm 65,169$ & 0.048 \\
\hline & $\begin{array}{l}\text { el and I risk } \\
(n=113)\end{array}$ & $\begin{array}{l}\text { el risk } \\
(n=31)\end{array}$ & $\begin{array}{l}\text { I risk } \\
(\mathrm{n}=82)\end{array}$ & P-value ${ }^{\dagger}$ \\
\hline All-cause death (in-hospital) & 0 & 0 & 0 & - \\
\hline Cardiac death (in-hospital) & 0 & 0 & 0 & - \\
\hline Stent thrombosis (in-hospital) & 0 & 0 & 0 & - \\
\hline Length of CCU stay (days) & $2.7 \pm 1.9$ & $4.4 \pm 5.4$ & $2.8 \pm 3.5$ & $<0.001$ \\
\hline Length of hospital stay (days) & $9.1 \pm 3.5$ & $11.7 \pm 4.3$ & $8.0 \pm 2.5$ & $<0.001$ \\
\hline Unplanned readmission in $\leq 28$ days (all) & $8(7.1)$ & $1(3.2)$ & $7(8.5)$ & 0.326 \\
\hline Unplanned readmission in $\leq 28$ days (cardiovascular) & $5(4.4)$ & $1(3.2)$ & $4(4.9)$ & 0.703 \\
\hline \multirow[t]{2}{*}{ DPC cost ( $¥)$} & $186,009 \pm 73,062$ & $195,591 \pm 75,820$ & $182,386 \pm 72,135$ & 0.491 \\
\hline & $\begin{array}{l}\mathrm{eH} \text { and } \mathrm{H} \text { risk } \\
(n=184)\end{array}$ & $\begin{array}{c}\text { eH risk } \\
(n=63)\end{array}$ & $\begin{array}{c}\text { H risk } \\
(n=121)\end{array}$ & P-value $^{\dagger}$ \\
\hline All-cause death (in-hospital) & $32(17.4)$ & $9(14.3)$ & $23(19.0)$ & 0.423 \\
\hline Cardiac death (in-hospital) & $26(14.1)$ & $8(12.7)$ & $18(14.9)$ & 0.687 \\
\hline Stent thrombosis (in-hospital) & $2(0.1)$ & 0 & $2(1.7)$ & 0.305 \\
\hline Length of CCU stay (days) & $5.7 \pm 6.1$ & $7.1 \pm 7.8$ & $5.0 \pm 4.8$ & 0.004 \\
\hline Length of hospital stay (days) & $16.5 \pm 15.0$ & $20.1 \pm 18.3$ & $14.6 \pm 12.7$ & 0.002 \\
\hline Unplanned readmission in $\leq 28$ days (all) & $8(4.3)$ & $1(1.6)$ & $7(5.8)$ & 0.185 \\
\hline Unplanned readmission in $\leq 28$ days (cardiovascular) & $5(2.7)$ & $1(1.6)$ & $4(3.3)$ & 0.496 \\
\hline DPC cost (¥) & $276,360 \pm 199,884$ & $280,869 \pm 234,112$ & $274,012 \pm 180,542$ & 0.574 \\
\hline
\end{tabular}

Data given as mean \pm SD or $n(\%)$. 'Student's t-test, Mann-Whitney U-test or chi-squared test. CCU, coronary care unit; DPC, Diagnosis Procedure Combination; eH, $\mathrm{H}$ equivalent; el, I equivalent; eL, L equivalent; H, high; I, intermediate; $L$, low; nARS, novel Acute Myocardial Infarction Risk Stratification.

is also similar. The length of hospitalization, however, was significantly shorter in each nARS risk group than in the corresponding pre-nARS risk group. The main reason for the short hospitalization period in the nARS group was the establishment of a graded rehabilitation program adjusted for each AMI risk level. Although cardiac rehabilitation in STEMI patients was recommended in the ACC/AHA guidelines, ${ }^{16}$ an in-hospital rehabilitation program for STEMI or AMI was not clearly described. Because the current Japanese guideline still recommends a 14-day rehabilitation program, ${ }^{17}$ the 5-day (L risk), 7-day (I risk), and 10-day (H risk) rehabilitation program ${ }^{7}$ would significantly shorten the length of hospitalization. Another reason for the short hospitalization period in the nARS group may be the early prescription of ACEI/ARB and $\beta$-blockers, as part of the $\mathrm{L}$ risk management strategy. In addition, the prescription rate of both ACEI/ARB and $\beta$-blockers at discharge was higher in the nARS group compared with the pre-nARS group. Early introduction of optimal medical therapy, which would be associated with better outcome in AMI patients, might reduce the length of hospitalization. ${ }^{18,19}$

The risk of shortening the length of hospitalization should be discussed. Early discharge may result in unplanned readmission. Although the length of hospitalization for AMI is longer in Japan than in Western countries, ${ }^{20}$ the rate of early unplanned readmission was significantly lower in Japan than in Canada or the USA. ${ }^{6,20}$ 
It would be important to shorten the length of hospitalization without increasing the unplanned readmission rate. In the present study, unplanned readmission in $\leq 28$ days was similar between the pre-nARS and nARS groups. Moreover, unplanned readmission in $\leq 28$ days was similar between eL risk vs. L risk, between eI risk vs. I risk, and between eH risk vs. H risk. Therefore, nARS was not associated with increased risk of unplanned readmission, suggesting the safety of nARS.

Clinical implications of the present study should be noted. Although the DPC cost for each patient was not different between the pre-nARS and nARS groups, shortening the length of hospitalization for each patient would save medical resources in the regional health-care system. ${ }^{21}$ Because beds for AMI patients are limited in both local and urban areas in Japan, ${ }^{22} \mathrm{nARS}$ may generate beds for additional AMI patients. Moreover, if there were no available CCU beds in the regional health-care system, AMI patients would miss the chance to receive appropriate acute care including primary PCI. The nARS system may therefore contribute to provide unoccupied beds in the regional health-care system by shortening the length of hospitalization for each AMI patient.

\section{Study Limitations}

First, this was a single-center, retrospective observational study, in which there is a risk of patient/group selection bias. Second, the nARS system was defined not for the purpose of the present study, but for the purpose of clinical stratification of AMI patients. Although we prospectively assigned patients with AMI to each risk group according to the nARS system, the present study analyzed those clinical data retrospectively. Moreover, the risk stratification in the pre-nARS group was retrospectively performed for this study. Third, because we could not perform a statistical power analysis, there is a possibility of $\beta$ error, meaning that a significant association between the pre$\mathrm{nARS}$ and nARS groups might have been missed. Fourth, the nARS system has 2 different purposes: one is risk stratification, and the other is the rehabilitation program. Because the risk stratification is closely linked to the rehabilitation, the impact of the risk stratification cannot be estimated separately in the present study. Finally, although we compared the impact of nARS utilization between the pre-nARS and the nARS groups, there were significant confounding factors such as different strategies for drug prescription and cardiac rehabilitation, which limits the reliability of the conclusion.

\section{Conclusions}

The length of CCU stay and hospital stay were significantly shorter in the nARS group compared with the pre-nARS group. The use of nARS may save medical resources for patients with AMI in the regional health-care system.

\section{Acknowledgments}

We are grateful for the support of the entire staff of the Coronary Care Units and Cardiovascular Division of Saitama Medical Center, Jichi Medical University.

\section{Disclosures}

This research was supported in part by a research grant from Boehringer Ingelheim. K.S. has received honoraria for speaking from
Abbott Vascular, Boston Scientific, Medtronic Cardiovascular, and Terumo; he has also served as a consultant for Abbott Vascular and Boston Scientific. The other authors declare no conflicts of interest.

\section{References}

1. Hao K, Yasuda S, Takii T, Ito Y, Takahashi J, Ito K, et al. Urbanization, life style changes and the incidence/in-hospital mortality of acute myocardial infarction in Japan: Report from the MIYAGI-AMI Registry Study. Circ J 2012; 76: 1136-1144.

2. Hata J, Ninomiya T, Hirakawa Y, Nagata M, Mukai N, Gotoh $\mathrm{S}$, et al. Secular trends in cardiovascular disease and its risk factors in Japanese: Half-century data from the Hisayama Study (1961-2009). Circulation 2013; 128: 1198-1205.

3. Hakkinen U, Rosenqvist G, Peltola M, Kapiainen S, Ratto H, Cots F, et al. Quality, cost, and their trade-off in treating AMI and stroke patients in European hospitals. Health Policy 2014; 117: $15-27$.

4. Sugiyama T, Hasegawa K, Kobayashi Y, Takahashi O, Fukui T, Tsugawa Y. Differential time trends of outcomes and costs of care for acute myocardial infarction hospitalizations by ST elevation and type of intervention in the United States, 2001-2011. $J$ Am Heart Assoc 2015; 4: e001445.

5. Soekhlal RR, Burgers LT, Redekop WK, Tan SS. Treatment costs of acute myocardial infarction in the Netherlands. Neth Heart J 2013; 21: 230-235

6. Wang Y, Eldridge N, Metersky ML, Sonnenfeld N, Fine JM, Pandolfi MM, et al. Association between hospital performance on patient safety and 30-day mortality and unplanned readmission for Medicare fee-for-service patients with acute myocardial infarction. J Am Heart Assoc 2016; 5: e003731.

7. Yamamoto K, Sakakura K, Akashi N, Watanabe Y, Noguchi $\mathrm{M}$, Taniguchi $\mathrm{Y}$, et al. Clinical outcomes after acute myocardial infarction according to a novel stratification system linked to a rehabilitation program. J Cardiol 2018; 72: 227-233.

8. Thygesen K, Alpert JS, Jaffe AS, Simoons ML, Chaitman BR, White HD, et al. Third universal definition of myocardial infarction. J Am Coll Cardiol 2012; 60: 1581 - 1598 .

9. Cutlip DE, Windecker S, Mehran R, Boam A, Cohen DJ, van Es GA, et al. Clinical end points in coronary stent trials: A case for standardized definitions. Circulation 2007; 115: 2344-2351.

10. Matsuo S, Imai E, Horio M, Yasuda Y, Tomita K, Nitta K, et al. Revised equations for estimated GFR from serum creatinine in Japan. Am J Kidney Dis 2009; 53: 982-992.

11. Fujii T, Suzuki T, Torii S, Murakami T, Nakano M, Nakazawa G, et al. Diagnostic accuracy of Global Registry of Acute Coronary Events (GRACE) risk score in ST-elevation myocardial infarction for in-hospital and 360-day mortality in Japanese patients. Circ J 2014; 78: 2950-2954.

12. Morrow DA, Antman EM, Charlesworth A, Cairns R, Murphy SA, de Lemos JA, et al. TIMI risk score for ST-elevation myocardial infarction: A convenient, bedside, clinical score for risk assessment at presentation: An intravenous nPA for treatment of infarcting myocardium early II trial substudy. Circulation 2000; 102: 2031-2037.

13. Yasunaga $\mathrm{H}$, Ide $\mathrm{H}$, Imamura $\mathrm{T}$, Ohe $\mathrm{K}$. Impact of the Japanese diagnosis procedure combination-based payment system on cardiovascular medicine-related costs. Int Heart J 2005; 46: $855-866$.

14. Wang K, Li P, Chen L, Kato K, Kobayashi M, Yamauchi K. Impact of the Japanese diagnosis procedure combination-based payment system in Japan. $J$ Med Syst 2010; 34: 95-100.

15. Rasteniene R, Aleksejuniene J, Puriene A. Determinants of length of hospitalization due to acute odontogenic maxillofacial infections: A 2009-2013 retrospective analysis. Med Princ Pract 2015; 24: 129-135.

16. Kushner FG, Hand M, Smith SC Jr, King SB 3rd, Anderson JL, Antman EM, et al. 2009 focused updates: ACC/AHA guidelines for the management of patients with ST-elevation myocardial infarction (updating the 2004 guideline and 2007 focused update) and ACC/AHA/SCAI guidelines on percutaneous coronary intervention (updating the 2005 guideline and 2007 focused update): A report of the American College of Cardiology Foundation/American Heart Association Task Force on Practice Guidelines. J Am Coll Cardiol 2009; 54: 2205-2241.

17. JCS Joint Working Group. Guidelines for the management of patients with ST-elevation acute myocardial infarction (JCS 2013). JCS guideline.

18. Ibanez B, Macaya C, Sanchez-Brunete V, Pizarro G, FernandezFriera L, Mateos A, et al. Effect of early metoprolol on infarct 
size in ST-segment-elevation myocardial infarction patients undergoing primary percutaneous coronary intervention: The Effect of Metoprolol in Cardioprotection During an Acute Myocardial Infarction (METOCARD-CNIC) trial. Circulation 2013; 128: $1495-1503$.

19. Roolvink V, Ibanez B, Ottervanger JP, Pizarro G, van Royen N, Mateos A, et al. Early intravenous beta-blockers in patients with ST-segment elevation myocardial infarction before primary percutaneous coronary intervention. J Am Coll Cardiol 2016; 67: $2705-2715$.

20. Tiessen J, Kambara H, Sakai T, Kato K, Yamauchi K, McMillan C. What causes international variations in length of stay: A comparative analysis for two inpatient conditions in Japanese and Canadian hospitals. Health Serv Manage Res 2013; 26: 86-94.

21. Motohashi T, Hamada H, Lee J, Sekimoto M, Imanaka Y. Factors associated with prolonged length of hospital stay of elderly patients in acute care hospitals in Japan: A multilevel analysis of patients with femoral neck fracture. Health Policy 2013; 111: 60-67.

22. Tomoike H, Yokoyama H, Sumita Y, Hanai S, Kada A, Okamura T, et al. Nationwide distribution of cardiovascular practice in Japan: Results of Japanese Circulation Society 2010 annual survey. Circ J 2015; 79: 1058-1067. 